\title{
Decellularization of tissues and organs
}

\section{Dokuların ve organların hücresizleştirilimesi}

\author{
Nevra Pelin Cesur, Volkan Yalman, Nelisa Türkoğlu Laçin
}

Yildiz Technical University, Molecular Biology and Genetics Department, Istanbul, Turkey

Corresponding author: Nelisa Türkoğlu Laçin, MD., Yildız Technical University, Molecular Biology and Genetics Department, Istanbul, Turkey

E-mail: nelisalacin@gmail.com

Received/Accepted: August 22, 2019 / July 06, 2020

Conflict of interest: There is not a conflict of interest.

\begin{abstract}
SUMMARY
Decellularized tissues and organs have been successfully used in various tissue engineering and regenerative medicine applications. A biological scaffold obtained from the extracellular matrix can be produced by a variety of decellularization methods that effectively remove cells from the tissue to be treated. Decellularization methods is changed according to the target structure of tissues and organs. These methods can be summarized with chemically, physically, enzymatically and using Supercritical Fluid Extraction (SFE) ways. Each of these methods affects the biochemical composition in the structure of the remaining extracellular matrix (ECM), the structure of the tissue (ultrastructure), and the mechanical behavior. In this article, the most commonly used decellulization methods are introduced and their effects on biological tissue scaffold materials are discussed.
\end{abstract}

Keywords: Extracellular matrix, decellularization, supercritical fluid extraction (SFE)

\section{ÖZET}

Hücresizleştirilmiş dokular ve organlar çeşitli doku mühendisliği ve rejeneratif tıp uygulamalarında başarıyla kullanılmıştır. Hücre dışı matristen elde edilen biyolojik bir iskele, tedavi edilecek dokuya ait hücreleri etkili bir şekilde uzaklaştıran çeşitli hücresizleştirme yöntemleri ile elde edilebilir. Hücresizleştirme yöntemleri, doku ve organların hedef yapısına göre değiştirilir. Bu yöntemler kimyasal, fiziksel, enzimatik ve süper kritik akışkan ekstraksiyonu (SFE) yöntemleri ile özetlenebilir. Bu yöntemlerin her biri, elde edilen hücre dışı matrisin (ESM) yapısındaki biyokimyasal bileşimini, dokunun yapısını (altyapı) ve mekanik davranışını etkiler. Bu makalede, en sık kullanılan hücresizleştirme yöntemleri üzerinde durulmuş ve bu yöntemler ile elde edilen biyolojik doku iskeleleri üzerindeki etkileri tartışılmıştır. Anahtar sözcükler: Hücre dişı matris, desellulizasyon, süperkrik akışkan ekstraksiyonu (SFE)

\section{INTRODUCTION}

In recent years; insufficiency of organs and tissues is one of the most critical health problems for humanity. Even many patients are waiting for donors, and the donor waiting list continues for a long time. Generally, the workflow begins with the transplantation of organs from donors. However, this procedure is not as easy as it seems. Because the compatibility of the tissues should be ensured, and acute rejection of the implanted graft should be prevented ${ }^{1}$. Therefore, one of the ways to solve this problem is the development of artificial tissues and organs by the help of tissue engineering (TE).

Tissue engineering is composed of three main factors; signal molecules, cells, and scaffolds complemented with each other. The piers are two types, synthetic and natural. Additionally; TE scaffolds, whether natural or synthetic, must be 
mechanically stable, biocompatible, sterile, porous, and of adequate strength ${ }^{2}$. However, maintaining the complexity of the cell microenvironment causes many difficulties in the use of synthetic scaffolds. Therefore, studies on the extracellular matrix (ECM) are increasing dramatically in all areas of the world ${ }^{3}$.

The extracellular matrix is the main part of the tissue without the cells on it with a highly organized structure. Collagen, elastin, fibronectin, laminin, glycoprotein, proteoglycan and glycosaminoglycan are the main macromolecular components of the ECM structure. The composition of ECM determines the mechanical and biochemical behavior of the tissue or organ. The mechanical behavior of a decellularized tissue/organ is critical for the re-celling procedures. It affects the proliferation efficiency of the cells on it. Thus, the combination and amount of the macromolecular components for each tissue is unique and critical for the determination of the cell fate. In addition, ECM mediates many functions such as cell growth, migration, differentiation, survival. It also plays protective and supportive role for tissue formation and rearrangement of dynamic cellular behavior ${ }^{4}$.

On the other hand; natural tissue scaffolds can be obtained by decellularization technology. The use of decellularized tissue matrices instead of tissue scaffolds prepared with synthetic materials is critical due to the ability to mimic the $3 \mathrm{D}$ natural structures of tissues while maintaining the biomechanical, structural and biochemical properties of the ECM ${ }^{3}$. The primary purpose of the decellularization process is to ensure the removal of cells and cell contents (genetic materials such as DNA or RNA) from the ECM ${ }^{5}$.

In addition, the resulting ECM will prevent the formation of an immunological and thrombogenic reaction when combined with the recipient's own stem cells. In short, using decellularized ECM, it would be possible to produce personalized tissues. Moreover, decellularization can be applied to the entire organ and various tissue fragments. Especially in the literature, there are many successful studies on heart, blood vessels, cartilage bone, adipose tissue, small intestine, umbilical cord and live $\mathrm{e}^{\mathrm{r}, 7}$. Figure 1 summarizes almost all types of processes in decellularization and recellularization techniques ${ }^{4}$.

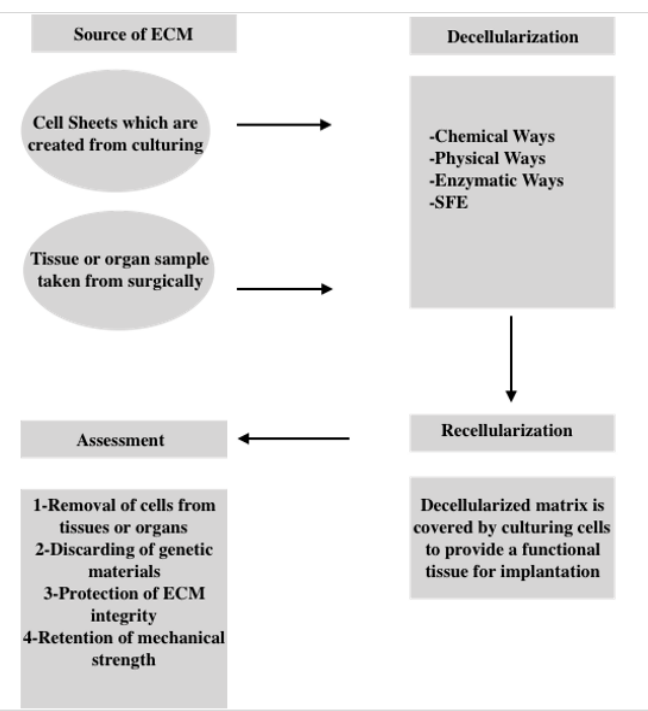

Figure 1: Decellularization and recellularization

processes

Decellularization is performed using a wide range of techniques which are mainly consisting of physically, chemically and enzymatically treatment methods ${ }^{8,9}$. Each of these methods affects the biochemical composition, the ultrastructure of the tissue, and the mechanical behavior of the remaining extracellular matrix (ECM) structure. Additionally, obtained ECM by decellularization has also been formed an antiinflammatory, immune response which can be associated with a reduced risk of rejection ${ }^{10,11}$. Although there is no universally accepted standard for the decellularization processes, if no cell nuclei was determined by using various staining methods after the decellularization processes, and amount of double-stranded DNA is less than $50 \mathrm{ng}$ for per $\mathrm{mg}$ of extracellular matrix, and the length of doublestranded DNA is less than $200 \mathrm{bp}$, this tissue can be evaluated as decellularized ${ }^{8}$.

\section{Deccellularization strategies}

\section{Physical methods}

Physical methods used to facilitate decellularization mainly include freezing, direct pressure, sonication, and agitation. Physical methods aim disrupting the cell membrane, releasing and removal of cell contents from the $\mathrm{ECM}^{12}$. The most preferred method among these methods is freezing. In particular, this method is mostly used in tendon, ligament, and nerve tissues ${ }^{13}$. This method is also called Freeze-Thaw method that is the process of freezing the tissue to $-86{ }^{\circ} \mathrm{C}$ and bringing it back to $37^{\circ} \mathrm{C}$ rapidly ${ }^{14}$. This rapid procedure leads to the disruption of the cellular 
membrane and cell lysis. Furthermore; the temperature rate is a very significant point for this physical method. Because temperature changes should be kept under control to inhibit the ice formation during ECM disruption ${ }^{12}$. Additionally, temperature difference or freeze-thaw cycles can be changed based on your specific protocol. For instance, in literature, two studies are available for freeze- thaw method which are decellularization of fibroblast cell sheets in three and canine lumbar spinal segments in one freeze-thaw cycle ${ }^{4}$. Although there is minimal damage to the ECM structure as a result of this method and GAG and collagen content, mechanical strength behaviors are almost identical with native specimens of tissues or organs, after the following treatment $88 \%$ of the genetic material is remained in the fibroblast cell sheets ${ }^{15,14}$. Consequently, the freeze-thaw method is beneficial for protection of biochemical components and biomechanical properties; however, because of the inadequate removal of genetic material, immune rejection is possible ${ }^{4}$.

\section{Chemical Methods}

On the other hand, decellularization can be performed using chemicals which are consisting of acid/alkali solutions, detergent, alcohols, and other elements. Mainly; alkali solutions and acids cause hydrolytic degradation in biomolecules such as nucleic acids and cytoplasmic cell contents. Peracetic acid (PAA) is one of the acidic solutions that is used for the removal of the remaining nucleic acids of the cells by showing a minimal effect on ECM structure ${ }^{16,17}$. However, although Peracetic acid has the effective ability to discard the genetic materials from the ECM, it can also interact with significant molecules such as glycosaminoglycans (GAGs) in ECM ${ }^{12}$. As a result of this, the mechanical strength of ECM is changed due to the interaction between PAA and GAGs (hyaluronic acid, heparin, heparin sulfate, chondroitin sulfate A and dermatan sulfate) ${ }^{17}$. At the other side of the chemical methods, sodium dodecyl sulfate (SDS), ionic detergents, and Triton $\mathrm{X}-100$, non-ionic detergents, demonstrate the intense detergent characteristics which are also reducers of the surface tensions. Although nonionic ones disrupt the lipid-lipid and lipid-protein interactions, they do not affect on protein-protein interactions so that proteins keep the functional conformation within the tissue or organ ${ }^{12}$. Rather than non-ionic detergents, ionic ones tend to disrupt the protein-protein interactions for solubilizing both cytoplasmic and nuclear cellular membranes ${ }^{18}$. Moreover, compared to the other detergents, SDS disrupt the native structure of tissue and lead to a decrease in the concentration of GAGs and ultimately to loss of collagen integrity in tissue. Decreasing amount of GAGs would decelerate the cell migration onto the scaffold and bioactivity of the scaffold ${ }^{12}$. Additionally, for both of the detergent types, due to their high affinity to the extracellular matrix, removal of all the toxin surfactants from the tissue is a complicated procedure ${ }^{1}$. As a result, a residue of these detergents can be remained inside the tissue and thus might cause undesired effects and cytotoxicity ${ }^{19}$.

\section{Enzymatic Approaches}

The enzymatic method is an another decellularization approach. Especially; nucleases (endo-exonucleases), trypsin, collagenase, lipase, dispase, thermolysin, and $\alpha$-galactosidase enzymes are used for the decellularization processes. They are particularly useful for the selective removal of cell debris and undesired ECM contents. Especially, trypsin is one of the most prevalent enzyme types in decellularization protocols which provides cleaving the peptide bonds between carbon side of arginine and lysine when the next residue is not proline ${ }^{20}$. However, only the enzymatic method is not fully adequate for cleaning inside the cell entirely. So, working together with a variety of chemicals is possible. For example, some studies showed that the more efficient decellularized tissue results were obtained with combined methods such as $0.05 \%$ trypsin, $0.02 \%$ EDTA, and agitation for $24 \mathrm{~h}$. However, this kind of enzymatic process has also an adverse effect on tissue structures. The prolonged treatment with trypsin/ EDTA can disrupt the ECM structure of native pulmonary valve, although there is not any effect on the amount of collagen within the tissue $^{21}$.

\section{Supercritical Fluid Extraction Methods}

The contrary of all other ways, nowadays; there is a new method that does not require multiple steps to be decellularized. It is called Supercritical Fluid Extraction (SFE) which involves the supercritical carbon dioxide to separate one component from another. This method is considerably different than in other decellularization ways. Usage of SFE leads to maximum removal of cells and cellular debris 
from tissues while ECM alterations are minimized 22.

scCO2 is a non-toxic, non-flammable, and relatively inert substance. In addition to these features, it has desirable properties as an appropriate solvent and has a mild critical temperature $\left(31.1{ }^{\circ} \mathrm{C}\right)$, which is suitable for physiologic environments. Because of these unique properties, it has been used for numerous biomedical applications such as extraction of biologically relevant molecules, pasteurization, and sterilization of synthetic and natural biomaterials ${ }^{22}$.

On the other hand; the most significant property of this fluid is that the transport coefficients ${ }^{1}$. The temperature and pressure of the supercritical fluid are higher than its critical point in which liquid and gas phases cannot be distinguished ${ }^{3}$. Particularly, this fluid has a unique property that can be behaved like a liquid-like density and a gas-like diffusivity/viscosity for transportation. Due to its convenient transport properties, the decellularization process by $\mathrm{scCO} 2$ shows considerably faster ${ }^{22}$. Thus, a supercritical fluid creates a high transfer and permeability rate ${ }^{4}$. Moreover, these rates can be changed and calibrated by altering temperature and pressure ${ }^{1}$. Notably, the parameters to create scCO2 above $31.1^{\circ} \mathrm{C}(304 \mathrm{~K})$ and 73.4 bar $(7.3 \mathrm{MPa})$ is also an alternative treatment for cytotoxic and calcifying diseases. Under these conditions, it can penetrate the tissues and dissolve the cells, which provides the removal of cells from the ${ }^{23}$. Figure 2 demonstrates these critic values for supercritical state.

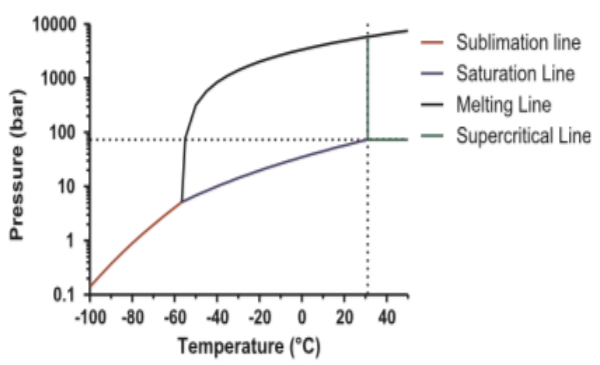

Figure 2: Supercritical phase diagram ${ }^{24}$

Furthermore, for minimum effect on the tissue structure, $\mathrm{scCO} 2$ can also be used for sterilization. $\mathrm{scCO} 2$ is an apolar substance so that ethanol is necessary to eliminate and deactivate charged molecules, for example, phospholipids ${ }^{3}$. On the other side, using ethanol with $\mathrm{scCO} 2$ ensures successful decellularization protocol for cornea, aorta, adipose tissues and esophagus ${ }^{24,25}$. Addition to these prospering properties of supercritical $\mathrm{CO} 2$, decellularization with utilizing of supercritical $\mathrm{CO} 2$, the content of collagen and elastin is not affected, and ultimately mechanical strength is not changed ${ }^{4}$. All of the these decellularization methods are summarized in Table1;

Table1: Decellularization Methods

\begin{tabular}{|l|l|l|l|}
\hline \multicolumn{1}{|c|}{ Physical Methods } & \multicolumn{1}{|c|}{ Chemical Methods } & Enzymatic Methods & \multicolumn{1}{|c|}{$\begin{array}{l}\text { Mechanical } \\
\text { Methods }\end{array}$} \\
\hline Mechanical Agitation & $\begin{array}{l}\text { Alkali-acid Solutions Acid, } \\
\text { (Deoxycholic } \\
\text { Peracetic Acid, Ammonium } \\
\text { Hydroxide) }\end{array}$ & $\begin{array}{l}\text { High } \\
\text { Hydrostatic } \\
\text { Pressure } \\
\text { (HHP) }\end{array}$ \\
\hline Freeze-Thaw Method & $\begin{array}{l}\text { Hypotonic and Hypertonic } \\
\text { Solutions } \\
\text { (EDTA, EGTA) }\end{array}$ & Lipase & $\begin{array}{l}\text { Supercritical } \\
\text { Carbon } \\
\text { Dioxide }\end{array}$ \\
\hline Sonication & $\begin{array}{l}\text { Non-ionic Detergents } \\
\text { (Triton X-100, Octyl gluco } \\
\text { pironidase (OGP)) }\end{array}$ & $\begin{array}{l}\text { a-galactosidase } \\
\text { Method }\end{array}$ \\
\hline NTIRE & $\begin{array}{l}\text { Ionic Detergents } \\
\text { (SDS, Triton X-200) }\end{array}$ & Thermolysis & \\
\hline Pressure-Force Methods & $\begin{array}{l}\text { Zwitterionic Detergents } \\
\text { (CHARPS) }\end{array}$ & Dispase & \\
\hline & Alcohols & Collagenase & \\
\hline & $\begin{array}{l}\text { Other solvents } \\
\text { (Acetone) }\end{array}$ & Endonucleases & \\
\hline & & Exonucleases & \\
\hline
\end{tabular}




\section{CONCLUSION}

Decellularization can be accomplished mainly with physical, chemical, and enzymatic ways. However, some of these protocols need to be used combined or respectively, to get the best results. Besides, each protocol will be dependent on the type of tissue interested because the structural and functional components of the ECM of various tissues will be different. On the other hand, although there are many various methods for decellularization of tissues, nowadays, SFE is a novel and popular method compared to other decellularization methods. Notably, the most remarkable properties of SFE are the protection of mechanical and biochemical strength of ECMs, sustainable biocompatibility, and prevention of immune rejection. These properties are very significant for studies of tissue engineering and wound healing. Additionally, tissues or organs can be obtained in absolutely dry conditions means that the semi permeability of the tissues/organs are protected that is vital for the recellularization of tissues. Therefore; SFE has got a considerable place for creating decellularized tissues or organs for obtaining valuable and desired ECM of tissues.

\section{REFERENCES}

1. Sawada K, Terada D, Yamaoka T, Kitamura S, Fujisato T. Cell removal with supercritical carbon dioxide for acellular artificial tissue. J Chem Technol. Biotechnol. 2008; 83(6):943-949.

2. Berthiaume F, Maguire TJ, Yarmush ML. Tissue Engineering and Regenerative Medicine: History, Progress, and Challenges. Annu Rev Chem Biomol Eng. 2011; 2:403-430.

3. Antons J, Marascio MG, Aeberhard P, et al. Decellularised tissues obtained by a CO2-philic detergent and supercritical CO2. Eur Cells Mater. 2018; 36:81-95.

4. A. Gilpin and Y. Yang, "Decellularization Strategies for Regenerative Medicine: From Processing Techniques to Applications," BioMed Research International. 2017.

5. A. D. Theocharis, S. S. Skandalis, C. Gialeli, and N. K. Karamanos, "Extracellular matrix structure," Advanced Drug Delivery Reviews. 2016.

6. P. M. Crapo, T. W. Gilbert, and S. F. Badylak, "An overview of tissue and whole organ decellularization processes," Biomaterials. 2011.

7. M. Katsimpoulas et al., "Investigation of the biomechanical integrity of decellularized rat abdominal aorta," Transplant. Proc., 2015.

8. N. Syazwani, A. Azhim, Y. Morimoto, K. S. Furukawa, and T. Ushida, "Decellularization of aorta tissue using sonication treatment as potential scaffold for vascular tissue engineering," J. Med. Biol. Eng., 2015.

9. H. Xu et al., "Comparison of decellularization protocols for preparing a decellularized porcine annulus fibrosus scaffold," PLoS One, 2014.

10. R. A. Hortensius and B. A. C. Harley, "Naturally derived biomaterials for addressing inflammation in tissue regeneration," Experimental Biology and Medicine. 2016.

11. A. Petrosyan et al., "A step towards clinical application of acellular matrix: A clue from macrophage polarization," Matrix Biol., 2017.

12. T. W. Gilbert, T. L. Sellaro, and S. F. Badylak, "Decellularization of tissues and organs," Biomaterials. 2006.

13. D. W. Jackson, E. S. Grood, B. T. Cohn, S. P. Arnoczky, T. M. Simon, and J. F. Cummings, "The effects of in situ freezing on the anterior cruciate ligament: An experimental study in goats," J. Bone Jt. Surg. - Ser. A, 1991.

14. İ. ÜÇGÜL and A. Sultan, "DESELÜLERIZZASYON YÖNTEMLERI VE DOKULARDA KULLANIMI," ANKA e-dergi, vol. 2, no. 2, pp. 19-34.

15. Q. Xing, K. Yates, M. Tahtinen, E. Shearier, Z. Qian, and F. Zhao, "Decellularization of fibroblast cell sheets for natural extracellular matrix scaffold preparation," Tissue Eng. - Part C Methods, 2015.

16. T. W. Gilbert, S. Wognum, E. M. Joyce, D. O. Freytes, M. S. Sacks, and S. F. Badylak, "Collagen fiber alignment and biaxial mechanical behavior of porcine urinary bladder derived extracellular matrix," Biomaterials, 2008.

17. J. Hodde and M. Hiles, "Virus safety of a porcinederived medical device: Evaluation of a viral inactivation method," Biotechnol. Bioeng., 2002.

18. A. M. Seddon, P. Curnow, and P. J. Booth, "Membrane proteins, lipids and detergents: Not just a soap opera," Biochimica et Biophysica Acta - Biomembranes. 2004.

19. H. C. Ott et al., "Perfusion-decellularized matrix: Using nature's platform to engineer a bioartificial heart," Nat. Med., 2008.

20. D. Voet, J. Voet, and C. Pratt, Fundamentals of 
Biochemistry life at the molecular level. 2011.

21. K. Schenke-Layland et al., "Impact of decellularization of xenogeneic tissue on extracellular matrix integrity for tissue engineering of heart valves," J. Struct. Biol., 2003.

22. D. M. Casali, R. M. Handleton, T. Shazly, and M. A. Matthews, "A novel supercritical CO2-based decellularization method for maintaining scaffold hydration and mechanical properties," $J$. Supercrit. Fluids, vol. 131, pp. 72-81, 2018.

23. C. A. Eckert, B. L. Knutson, and P. G.
Debenedetti, "Supercritical fluids as solvents for chemical and materials processing," Nature, 1996.

24. F. R. Halfwerk, J. Rouwkema, J. A. Gossen, and J. G. Grandjean, "Supercritical carbon dioxide decellularised pericardium: Mechanical and structural characterisation for applications in cardio-thoracic surgery," J. Mech. Behav. Biomed. Mater., 2018.

25. S. Guler, B. Aslan, P. Hosseinian, and H. M. Aydin, "Supercritical Carbon Dioxide-Assisted Decellularization of Aorta and Cornea," Tissue Eng. - Part C Methods, 2017. 